\title{
Are infestations of Cymo melanodactylus killing Acropora cytherea in the Chagos archipelago?
}

Received: 15 March 2010/Accepted: 19 June 2010/Published online: 7 July 2010

(C) Springer-Verlag 2010

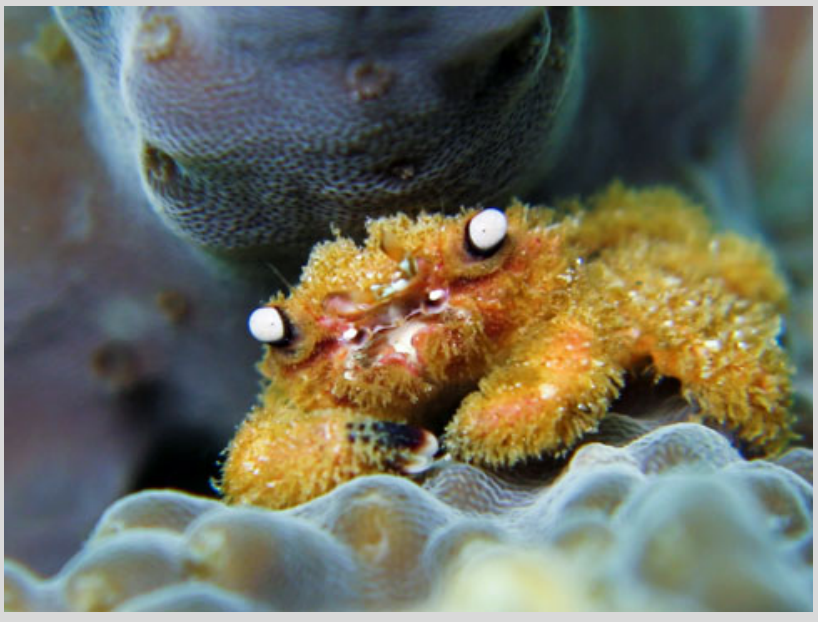

Fig. 1 Cymo melanodactylus on Acropora (Photo by Brian Mayes)

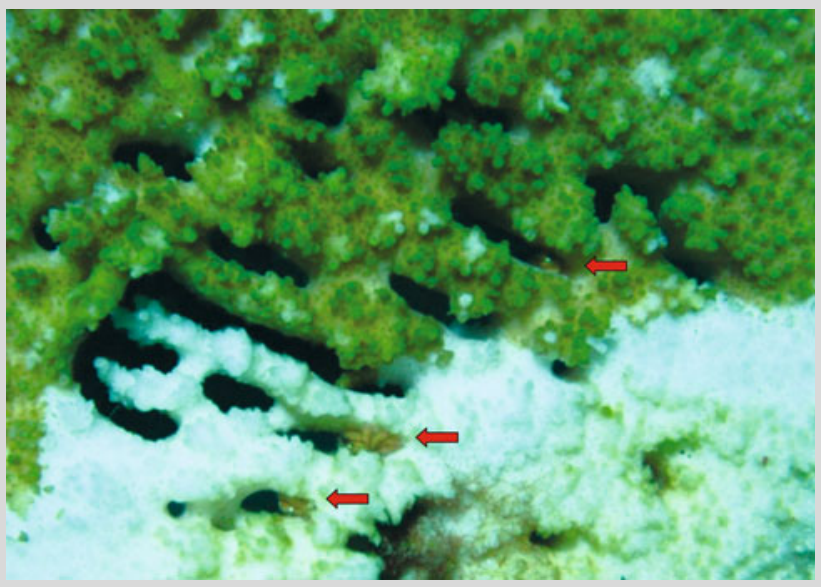

Fig. 2 Cymo melanodactylus (indicated by arrows) associated with recently dead areas of Acropora cytherea
Associations between branching corals and infaunal crabs are well known, mostly due to the beneficial effects of Trapezia and Tetralia crabs in protecting host corals from crown-of-thorns starfish (e.g., Pratchett et al. 2000) and/or sedimentation (Stewart et al. 2006). These crabs are obligate associates of live corals and highly prevalent across suitable coral hosts, with 1-2 individuals per colony (Patton 1994). Cymo melanodactylus (Fig. 1) are also prevalent in branching corals, mostly Acropora, and are known to feed on live coral tissue, but are generally found in low abundance $(<3$ per colony) and do not significantly affect their host corals (e.g., Patton 1994). In the Chagos archipelago, however, infestations of Cymo melanodactylus were found on recently dead and dying colonies of Acropora cytherea.

Acropora cytherea is commonly dominant between 5 and $15 \mathrm{~m}$ depth at moderately exposed locations throughout Chagos. At several locations visited in February 2010, approximately 5\% of these colonies had conspicuous evidence of recent tissue loss (Fig. 2).

Close inspection of these colonies revealed localized infestations (up to 47 crabs per colony) of $C$. melanodactylus mostly located within the area of recent tissue loss or along the tissue margin (Fig. 2).

Conversely, these crabs could not be found on healthy colonies of A. cytherea, or on dead colonies.

Given the high densities of $C$. melanodactylus and their proximity to the dead tissue front, it seems that these crabs may be causing or contributing to observed coral mortality. Alternatively, these corals may be dying due to other causes (e.g., coral disease) and like many other corallivores (e.g., McIlwain and Jones 1997), C. melanodactylus may feed selectively on injured corals.

Acknowledgments The Chagos Research Expedition of 2010, funded largely by the FCO, London enabled this work to take place. Additional funding provided by Queensland Smart Futures Fund.

\section{References}

McIlwain JL, Jones GP (1997) Prey selection by an obligate coral-feeding wrasse and its response to small-scale disturbance. Mar Ecol Prog Ser 155:189-198

Patton WK (1994) Distribution and ecology of animals associated with branching corals (Acropora spp.) from the Great Barrier Reef, Australia. Bull Mar Sci 55:193-211

Pratchett MS, Vytopil E, Parks P (2000) Coral crabs influence the feeding patterns of crown-of-thorns starfish. Coral Reefs $19: 36$

Stewart HL, Holbrook SJ, Schmitt RJ, Brooks AJ (2006) Symbiotic crabs maintain coral health by clearing sediments. Coral Reefs 25:609-615

M. S. Pratchett $(\bowtie)$ N N. A. J. Graham

ARC Centre of Excellence for Coral Reef Studies, James Cook University, Townsville Q4811, Australia

e-mail: morgan.pratchett@jcu.edu.au

C. R. C. Sheppard

Department of Biological Sciences, University of Warwick, Coventry CV4 7AL, UK

B. Mayes

6 Warwick House, Sutton Coldfields, West Midlands, UK

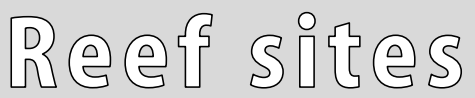

Coral Reefs (2010) 29:941

DOI $10.1007 / \mathrm{s} 00338-010-0654-\mathrm{x}$ 